\title{
Human Resource Practices and Work-Family Conflict: the Role of Family and Work Status
}

\author{
Kaumudi Misra, Ph.D. \\ Assistant Professor, Department of Management \\ College of Business and Economics, \\ California State University East Bay \\ 25800 Carlos Bee Blvd., VBT 357 \\ Hayward, CA 94542, USA. \\ E-mail: kaumudi.misra@csueastbay.edu
}

\author{
Stephanie Seitz, Ph.D. \\ Assistant Professor, Department of Management \\ College of Business and Economics, \\ California State University East Bay \\ 25800 Carlos Bee Blvd. \\ Hayward, CA 94542, USA.
}

Fnu Bithika, M.S. Business Analytics

College of Business and Economics,

California State University East Bay

25800 Carlos Bee Blvd.

Hayward, CA 94542, USA.

Received: Sep. 15, 2019 Accepted: Oct. 6, 2019 Online published: Oct. 28, 2019

doi:10.5296/ijhrs.v9i4.15443 URL: https://doi.org/10.5296/ijhrs.v9i4.15443 


\section{Abstract}

According to role theory, employees experience conflict between their enacted roles in the work versus family domain, often resulting in negative individual and organizational outcomes. Flexible work practices such as flextime, in tandem with other HR practices such as higher pay levels or team-based work, have thus gained popularity for their positive impact on employees' work-family conflict. Related individual variables such as age, gender or family status have also generated research interest owing to their anticipated effects on work-family conflict. However, extant studies have not tested the simultaneous effects of organizational and individual variables on the relationship between HR practices and employee work-family conflict. Using data from the UK Work-Life Balance Study 2011-12 funded by the Economic and Social Research Council, this study tests the effects of HR practices (compensation, team-based work, and flexible work practices) as well as individual variables (gender, family status and managerial status) on employees' perceived work-family conflict. Results show that gender, family status and managerial status moderate the relationship between flextime and work-family conflict, shedding new light on the differential impact of flextime on different categories of employees - men versus women; married versus unmarried; and managerial versus non-managerial. Conceptual and practical implications are discussed.

Keywords: flextime, work-family conflict, HR practices, gender, work and family

\section{Introduction}

Strategic human resource management scholars have been interested in both individual as well as organizational level outcomes since decades. The effects of human resource (HR) practices such as training, communication, compensation, pay-for-performance, self-directed teams have been advocated as high performance work practices that enhance individual as well as organizational performance (Huselid, 1995; Appelbaum, Bailey, Berg and Kalleberg, 2000; Becker and Huselid, 2006; Jiang, Lepak, Hu, and Baer, 2012). More recently, flexible work practices have been advocated as one of the important ways in which HR practices can improve individual (e.g. Eaton, 2003; De Menezes and Kelliher, 2017) as well as organizational performance (e.g. Perry-Smith and Blum, 2000; Beauregard and Henry, 2009). Flexible work practices such as flextime, compressed workweeks and telecommuting have been shown to have a positive impact on employee work-family outcomes, especially when used in tandem with other HR practices such as higher pay levels or team-based work that provides peer support to employees.

On the other hand, according to role theory, employees experience conflict between their enacted roles in the work versus family domain, often resulting in negative outcomes such as stress and work-family conflict. Employees' personal situations have also been proposed as the potential reason behind the felt conflict between employees' work and family demands. For example, employees with children or elderly to care for at home may experience increased demands from the home front (Voydanoff, 1988; Goff, Mount, and Jamison, 1990; Nomaguchi and Fettro, 2017). Also, employees' marital status has been shown to affect their experienced levels of work-family conflict. Similarly, employees' work status may could also have implications for their experienced role conflict. Voydanoff's (1988) study theoretical 


\section{Macrothink}

International Journal of Human Resource Studies

ISSN 2162-3058 2019, Vol. 9, No. 4

framework includes aspects of the family and work domain that collectively affect employee work-family conflict. For example, managerial employees face an increased time and energy demand at the workplace. Managers are non-exempt employees and are not paid for working after hours. Their job definition includes an expectation that they will be available to resolve workplace problems on a need basis. In order to understand a more complete set of factors affecting employee work-family conflict, research must consider the impact of both aspects of an employees' day to day life - both family as well as work roles.

This study provides an empirical test of the simultaneous effects of HR practices (such as compensation, team-based work, and flexible work practices) as well as individual variables (such as gender, family status and managerial status) on employees' perceived work-family conflict. Using data from the UK Work-Life Balance Study 2011-12 funded by the Economic and Social Research Council, Results show that both gender and family status (family roles) and managerial status (work role) moderate the relationship between flextime and work-family conflict, shedding new light on the differential impact of flextime on separate categories of employees - men versus women; married versus unmarried; and managerial versus non-managerial.

Figure 1 presents our hypothesized conceptual model to be tested.

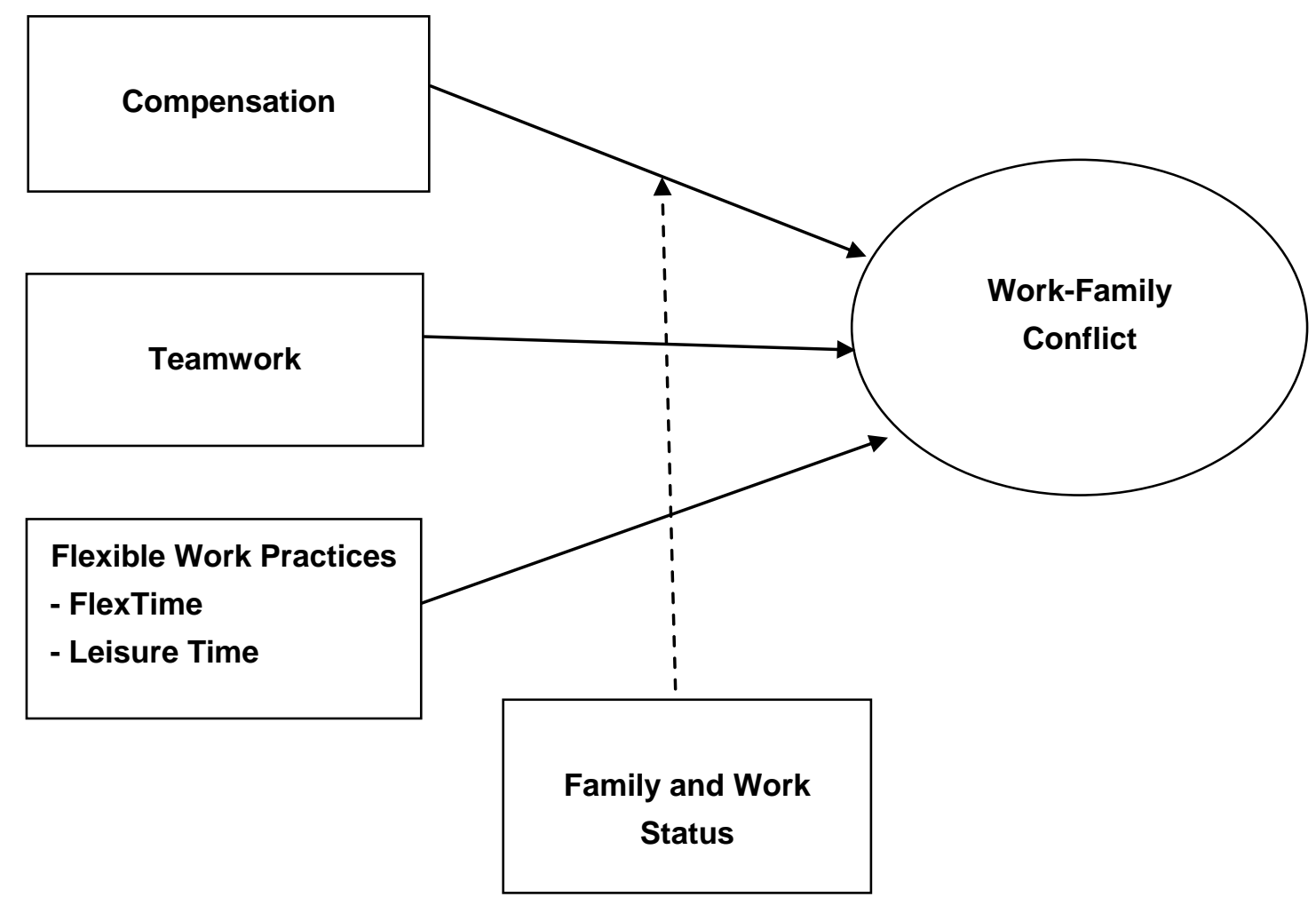

Figure 1. Conceptual model to be tested 


\section{Literature Review and Hypotheses Development}

\subsection{Human Resource Practices and Work-Family Conflict}

A well-researched area of in human resource management has been the study of the effect of HR practices on the work and family lives of individuals. Scholars have studied the work and life situations of dual-earner families for decades (Kossek and Nichols, 1992; Kossek, Colquitt, and Noe, 2001; Hammer, Neal, Newsom, Brockwood, \& Colton, 2005; Park \& Fritz, 2015; Matias, Ferreira, Vieira, Cadima, Leal, \& Mena Matos, 2017; Crawford, Thompson, \& Ashforth, 2019). With an increasing number of dual-career households, the demands of working time while simultaneously providing care for children or sick family members is a challenge faced by almost all employees today. As such, addressing the family pressures of individual employees is of imminent concern to employers (Kossek, Colquitt, and Noe, 2001; Duxbury \& Dole, 2015; Bernardo, Paleti, Hoklas, \& Bhat, 2015; Vieira, Matias, Lopez, \& Matos, 2016; Neal \& Hammer, 2017). Research attention has been drawn to the use of strategic HR practices to enhance the work-family balance of individual employees (Perry-Smith and Blum, 2000; White, Hill, McGovern, Mills, \& Smeaton, 2003; Berg, Kalleberg, \& Appelbaum, 2003; Batt and Valcour, 2003; Shih, Chiang, \& Hsu, 2010). Long working hours, overtime work and conflicts with coworkers regarding schedules or work hours can reduce employees' experienced work-family balance (Greenhaus and Buetell, 1985; Frone, Russell, and Cooper, 1992). Modern-day workplaces that emphasize teamwork can also have a negative effect on the work-family balance of employees as members need to match work schedules for team meetings and group-based work (Batt and Valcour, 2003).

The work-family literature has discussed the conflict between work and family domains faced by individual employees for a long time now. Research on the 'work-family conflict' construct has highlighted varied sources of role conflict faced by individuals as they perform simultaneous work and family roles (Katz and Kahn, 1978; Greenhaus and Beutell, 1985). Role theory suggests that individuals who participate in multiple roles (such as in two different types of jobs, or in two different types of roles, e.g. in the work and family domains) inevitably experience conflict. Based on a scarcity hypothesis that assumes a fixed amount of time and human energy, Greenhaus and Beutell (1985) identified three sources of role conflict: According to them, competing expectations from performing work-roles and family-roles may cause individuals to experience at least one or more of three types of conflict.

First, time-based conflict may arise from the number of hours worked, overtime and shift work, or the lack of consistency of work schedules. In addition, marital status, number and ages of kids, spousal employment patterns could also impact the time available to employees to balance their work and family roles (Pleck et al., 1980; Keith and Schafer, 1980; Greenhaus and Kopelman, 1981; Beutell and Greenhaus, 1982). Second, employees may experience strain-based conflict owing to work hours that come in the way of their ability to perform their family roles. Third, studies have suggested that behaviors expected from employees at the workplace may significantly differ from behaviors expected from them at home, resulting in behavior-based conflict (Bartolome, 1972; Burke, Weir, and DuWors, 1979; Greiff and Muntor 1980). 
Strategic HR practices have been designed to give employees more autonomy at the workplace to adjust their schedules and work pace so that they are better able to balance their work and family lives. While some changes in human resource practices at the workplace have brought about more job autonomy for workers, there is also evidence that these changes have led to higher levels of work pressure and work strain (Cappelli et al., 1997; Gallie, 2002). Studies have found that the pace of technological change makes work more intense and impacts the psychological strain on workers (Green and McIntosh. 2001; Green 2001; Green, 2002; Fagan and Burchell, 2002).

Some studies on HR practices have even assessed the negative impact of these practices on individual employees. For example, Ramsay, Scholarios, and Harley (2000) showed that HR practices designed to increase organizational performance may have a negative impact on employees by making them work harder. The HR "best practices" approach is based on the principle that more autonomy and opportunity to participate in decision-making improves employee motivation, resulting in better performance (Appelbaum, Bailey, Berg and Kalleberg, 2000; Lepak, Liao, Chung and Harden, 2006). However, autonomy and enhanced participation in workplace decisions could sometimes translate into extra effort on the part of employees. Autonomy comes with increased responsibilities that may create additional burden on employees. These arguments point to the reasons high-performance HR practices, or "best practices" may sometimes result in more intensive work and time pressures for individuals. Evidence from research at the turn of the century has pointed that high-performance HR practices potentially increase the stress of individual employees while improving organizational performance (Ramsay et al., 2000; White et al., 2003). A few researchers have examined the effects of "high performance" or "high commitment" HR practices on employee work-family balance (Batt and Valcour, 2003; Berg et al, 2003). In particular, Batt and colleagues $(2002 ; 2003)$ argue that high-performance HR practices such as self-managed teams can impact the work-life balance of team members negatively.

\subsection{Pay Levels and Work-Family Conflict}

One of the most important facets of HR practices is related to pay and incentives. Compensating employees for their contributions to the organization have been related to positive outcomes such as job satisfaction, organization commitment, as well as work-life balance. Berg et al. (2003) show that pay-for-performance plans have a significant, positive effect on the work-life balance of employees in the manufacturing sector (2003:181). The positive impact of the satisfaction from appropriate levels of pay and incentives has been shown to compensate for the role conflict that employees may face while fulfilling their work and family roles (Berg et. al., 2003; Batt \& Valcour, 2003; Ratten, Ryan, \& Sagas, 2009). Higher levels of pay and pay satisfaction helps employees with conservation of resources that they may lose as they contribute their efforts and time at the workplace. It also mitigates some of the rising costs of childcare or eldercare if the employee has to meet those costs as well. Therefore, we propose that pay levels will have a direct, negative effect on the work-family conflict of employees. 
H1: HR practices such as high relative pay will be negatively related to employees' work-family conflict.

\subsection{Teamwork and Work-Family Conflict}

Participation in teams has also been identified as one of the antecedents of work-life outcomes for employees (Berg et al., 2003; Batt and Valcour, 2003; Zhang, \& Liu, 2011). The high-performance work system paradigm has shown that the implementation of a set of HR best practices enhance organizational performance. However, one of the criticisms of research on high-performance work systems has been that these set of HR practices may have negative effects on individual employees. For example, one of the best practices espoused in this paradigm is the use of self-managed teams. Self-managed teams provide more autonomy to individual members to enable them to decide how and when they complete their assigned tasks. This decision-making ability motivates employees to perform better, resulting in better overall organizational performance. But teamwork may not be all good news. Team members have to make themselves available whenever the majority of the team decides to meet, even if the time may not be suitable to the individual needs of certain members. This temporal "bind" (Hochschild, 1997) can negatively affect the well-being of individual employees (White et al, 2003). Participative decision-making also comes with its associated negative effects for employees. Bailyn and others suggest that employees may, in fact, benefit from a standard work schedule as opposed to team-based schedules (Bailyn 1993; Bailyn, Rapoport, and Fletcher 2000; Perlow, 1997). Bailyn's research showed that engineers at Xerox, worked long hours, had very long meetings, and spent a lot of time at the workplace owing to stringent documentation requirements, as they had to coordinate work with their teams. Coupled with managerial interference during their daytime work hours, this meant that the engineers did their actual product development before or after normal working hours. The abnormal, as well as long work hours interfered with the Xerox engineers' family lives and resulted in a vicious cycle of long hours, high stress, and low productivity. As such, we hypothesize that teamwork will increase the work-family conflict faced by employees.

H2: HR practices such as teamwork will be positively related to employees' work-family conflict.

\subsection{Flextime and Work-Family Conflict}

Ample research evidence has pointed to the positive outcomes of flexible work arrangements for employees (Kossek and Ozeki 1998; Adams and Jex, 1999; Baltes et al.1999; Golden, 2001; Goldenhar, 2001). A spectrum of work-life flexibility practices have been implemented by organizations as an effective human resource management tool (Kossek and Ozeki, 1999; Perry-Smith and Blum, 2000; Reilly, 2001; Batt and Valcour, 2003; Eaton, 2003; Kossek and Van Dyne, 2008; Kossek, Baltes and Matthews, 2011).

Work-life flexibility policies and practices such as flextime, com[pressed work weeks, compensatory time off or telecommuting allow employees to adjust their work timing and place so that they are better able to balance their lives within and outside of work. This ability to alter schedules can have a direct, significant effect on employees' work-family conflict. First, 
control over one's own work schedule can mitigate any negative effects of time-based conflict on the work-family balance of employees (Thomas and Ganster, 1995; Tausig and Fenwick, 2001; White, Hill, McGovern, Mills and Smeaton, 2003). Second, freedom to manage their own work hours, rather than having it pre-determined for them, has a direct effect on employees' strain-based conflict (Christensen \& Staines, 1990; Allen, Johnson, Kiburz, \& Shockley, 2013). In fact, Byron's (2005) meta-analyses identified "hours worked" as well as "control over work schedule" as important antecedents of work-family conflict.

Flexible work practices such as flextime, compressed work weeks, compensatory time off, telecommuting, or personal time off, help reduce the time demands faced by employees, and enable them to contribute more at the workplace. Therefore, we propose that flexibility in work hours and the availability of leisure time will help employees' focus their attention on their job when they can be completely 'available' (both mentally and physically) to engage in their work. In addition, employees benefit from flextime and leisure time as both of these facilities help them to relax and get rejuvenated before they return to work. Employees can spend more time with their families and take care of their personal roles, which will reduce their work-family conflict (Greenhaus and Beutell, 1985; Kelloway, Gottlieb, and Barham; 1999; Allen, Johnson, Kiburz, \& Shockley, 2013).

Moreover, flextime helps facilitate team work so that team members have the flexibility to adjust their work schedules in coordination with their team meeting times. Flexible working practices also allow teams to set deadlines around the hours worked by members so that these deadlines can be met in time. As such, the use of flextime will help teams function more effectively and reduce strain from the inherent conflict faced by employees as they juggle between work and family roles.

H3: Use of Leisure Time will be negatively related to employees' work-family conflict.

H4: Use of Flextime will be negatively related to employees' work-family conflict.

\subsection{Work-Family Conflict and Gender}

Even though gender egalitarianism is increasing in the modern-day economy with the traditional male breadwinner model taking a backseat, women still remain the primary caregivers at home. As such, employed women often report higher levels of perceived work to family conflict and lower work-family balance (Loerch, Russell, and Rush, 1989). A review by Albertsen, Rafnsdóttir, Grimsmo, Tómasson, \& Kauppinen (2008) found that longer working hours were associated with lower work-family balance, with women more consistently reporting lower work-life balance in a majority of the studies reviewed. Further, overtime work was associated with lower work-family balance for women, but not for men (2008:15). In addition, women working part-time reported higher levels of work-life balance than their male counterparts. Seminal studies of gender differences and experienced work-family conflict have concluded that behavioral norms associated with gender largely determine work and family roles, resulting in working women experiencing higher levels of work-family conflict (Loerch, Russell, and Rush, 1989; Duxbury and Higgins, 1991). Further, in their 1994 study, Duxbury and colleagues also found that women reported higher levels of workload and work-family 
interference than men (Duxbury, Higgins, \& Lee, 1994). More recent studies show similar results with women reporting higher levels of work-family conflict (see Grönlund and Öun, 2018 for example).

While flexible work arrangements have been introduced with a view to help all employees manage their work and family demands, scholars have been interested in studying the differential effects of flexible work practices for men versus women. Results reveal that women potentially benefit more from flexible work practices, resulting in better workplace outcomes for them. For example, Scandura and Lankau (1997) found that women in organizations that offered flexible work hours reported higher levels of job satisfaction than their male counterparts. Similarly, in a study of Irish workers, Russell and McGinnity (2009) found that the use of time-related flexible work practices was gendered - with more women than men using flexible work practices such as job sharing, telecommuting, and reduced work hours. The findings are in line with our initial proposition that because women are still the primary caregivers at home, they experience higher levels of work-family conflict than their male counterparts. As such, women benefit from the flexible work practices available to them. For men, this benefit is even further enhanced with the availability of flexible work practices since their perceived work-family conflict levels are already lower than that of women.

Given the important role played by gender in the way work-family conflict is experienced by employees and the role of flexible work practices, we propose that gender will moderate the relationship between flextime and work-family conflict, such that the negative relationship between flextime and work-family conflict will be stronger for men than for women.

H5: Employees' Gender will moderate the relationship between their use of flextime and perceived work-family conflict, such that the negative relationship between use of flextime and work-family conflict will be stronger for men compared to women.

\subsection{Work-Family Conflict and Family Status}

Research has also shed light on the role of family responsibilities and family status as a factor affecting the perceived work-family conflict levels of employees. Studies have consistently found an association between family responsibilities and marital status on work-family conflict (Fu and Shaffer, 2001; Sturges and Guest, 2004; Shockley and Allen, 2007). Employees who have more family responsibilities report higher levels of work-family conflict and family to work interference. Fu and Shaffer (2001) hypothesized that being married will increase household responsibilities and hence work-family conflict levels. However, their study found an opposite effect. Being married may help employees to share the burden of family responsibilities as well as the strain from work, thus helping them perceive reduced work-family conflict levels. The use of flexible work practices such as flextime can further help married or partnered employees with lower work-family conflict levels.

On the other hand, single employees benefit from less household responsibility and have more flexibility with the way they choose to spend their time and energy (Herman and Gyllstrom, 1977). They are also almost always free from parental responsibilities, which has been shown to increase perceived work-life conflict (Voydanoff, 1988; Loerch et al., 1989). Hence we 
propose that employees' marital status will moderate the relationship between their use of flextime and perceived work-family conflict, with single employees benefitting more from flextime rather than married employees.

H6: Employees' Family Status will moderate the relationship between their use of flextime and perceived work-family conflict, such that the negative relationship between flextime and work-family conflict will be enhanced for single employees compared to married employees.

\subsection{Work-Family Conflict and Work Status}

Because work-family conflict is an outcome of the temporal and energy conflicts faced by employees between their work and home domains, managers and senior employees are presumably particularly affected by this imbalance as they face stringent job and time demands at the workplace (Kasper, Meyer, and Schmidt, 2005; Stock, Bauer, and Bieling, 2014). Although role theory directly points to the imbalance of time-based and strain-based effects of managerial roles on perceived work-family conflict (Greenhaus and Beutell, 1985), studies on the topic have mostly focused on the context by choosing managerial samples to generate or test hypotheses (see Linehan and Walsh, 2000; Lingard and Francis, 2005; Hoobler, Wayne, and Lemmon, 2009; Stock, Bauer, and Bieling, 2014 for examples). Role theory suggests that employees' use of time and energy in one role (work) will compensate their use in another role (family). Given that managers are expected to spend relatively higher amounts of time and energy taking care of their job demands, they not only face increased levels of work-family conflict but may not benefit from the use of flexible work practices as much as non-managers. We propose that employee work status will affect their work-family conflict, such that being a manager will moderate the relationship between flextime and managers' experienced work-life conflict.

H7: Employees' Work Status will moderate the relationship between their use of flextime and perceived work-family conflict, such that the negative relationship between flextime and work-family conflict will be enhanced for non-managers compared to managers.

\section{Method}

\subsection{Data and Sample}

Our data analysis uses the fourth Work-Life Balance Employee Survey (WLB4) carried out by the United Kingdom Department of Business, Innovation and Skills (Tipping, Chanfreau, Perry \& Tait, 2012). The WLB4 is a survey of working adults on work-life balance practices in their organizations. It aims at assessing the accessibility and use of work-life balance practices and their impact on employees. The telephone survey was administered to a sample of approximately 4109 households with eligible working adults. Of these, 1874 individuals responded to the survey, yielding a response rate of $45.6 \%$. A boost sample of individuals with kids and those who provided adult care were added on to the main survey, yielding 893 responses making the total number of individuals included in the final sample equal to 2767 . 
After eliminating missing data on variables of interest in our study, we had complete data for 1141 individuals.

\subsection{Analyses}

All analyses were performed using ordinary least squares regression. The analytical approach involves hypothesis tests for: (1) the direct effects of compensation, teamwork, flextime and leisure time, on individual work-family conflict; (2) the moderating effects of gender on the relationship between flextime and work-family conflict; (3) the moderating effects of family status on the relationship between flextime and work-family conflict; and (4) the moderating effects of managerial status on the relationship between flextime and work-family conflict

To test hypotheses and estimate the path coefficients, we compute composite measures of each of the HR practices. Composites are created for the Work-Family Conflict, Compensation, Teamwork, Flextime, and Leisure time variables based on the related individual items as described in the measures section below. Other variables used in the analyses (Age, Gender, Family Status and Work Status) are single-item measures.

\subsection{Measures}

\subsubsection{Work-Family Conflict}

We used four items from the WLB4 to measure work-life conflict based on prior studies (e.g. Haar, 2013; Tausig \& Fenwick, 2001). Employees who were using flexible work practices were asked if it gives them "more free time", "allows them to care for someone", or "blurred boundaries between work and home". Responses were recorded as Yes or No. A composite measure of work-family conflict was created based on the four items.

\subsubsection{Compensation}

Employees who currently used flexible work practices were asked if it has a negative consequence making them "receive lower pay/salary", or a positive consequence of "less travelling cost". Items were appropriately reverse coded to create the "compensation" measure.

\subsubsection{Teamwork}

Employees who used flexible work practices were asked if they had "less interaction with colleagues" or were "unable to attend meetings". Two Yes/No responses were recorded, and a composite was computed to create the variable 'Teamwork'.

\subsubsection{Flextime}

Employees using flexible work practices flexibly were asked if it resulted in them getting 'no flexibility over holiday time', or if it had the positive consequence of 'convenience and suitability'. Yes/No responses were recorded, and items were reverse coded to create the 'Flextime' variable. 


\subsubsection{Leisure Time}

Employees using flexible work practices flexibly were asked if it had the positive consequence of them getting 'time to study/complete a course', or "do hobbies/time for other interests". Yes/No responses were recorded, and a composite measure of 'Leisure Time' was created.

\subsubsection{Work Status}

This is a binary variable indicating whether the respondent employee was a manager or not ( $0=$ no; $1=$ yes $)$.

\subsubsection{Family Status}

This is a binary variable indicating whether the respondent employee was married $(=1)$ or unmarried $(=0)$.

\subsubsection{Gender}

Gender of the respondent employee was recorded as a binary variable ( $0=$ female; $1=$ male).

\section{Results}

We conducted our analyses in four steps. (1) First we tested the relationship between each HR practice and work-family conflict. Next, we ran a series of regression analyses to examine the moderating role of (2) gender, (3) family status, and (4) work status by introducing the interaction terms of HR practices with gender, marital status, and managerial status of employees. Table 1 presents the descriptive statistics and correlations between all variables included in our models. Table 2 shows the results of ordinary least squares regression analysis for the direct and moderated effects.

\subsection{Main Effects of HR Practices on Work-Family Conflict}

Hypotheses H1 through $\mathrm{H} 4$ assess the direct effects of the four HR Practices (Compensation, Team Work, Leisure Time and Flextime) on Work-family conflict. Control variables included are age, gender, marital status, and managerial status. Model 1 in Table 2 summarizes the results, including model $\mathrm{R}^{2}$.

In support of $\mathrm{H} 1$, compensation had a significant negative effect on employee work-family conflict $(\beta=-0.08, \mathrm{p}<0.01)$, but contrary to $\mathrm{H} 2$, the effect of team work on work-family conflict was not statistically significant. Between the two flexible work practices (Leisure Time and Flextime), only flextime had a significant negative effect on work-family conflict $(\beta=-0.11, p<0.01)$. Thus, H4 was supported, while the data did not provide support for H3. Results also show that gender, marital status and managerial status had significant, direct effects on work-family conflict $(\beta=0.03, \mathrm{p}<0.01 ; \beta=-0.03, \mathrm{p}<0.01 ;$ and $\beta=-0.03, \mathrm{p}<0.05$ respectively). The model $R^{2}$ is 0.07 . 
Table 1. Descriptive statistics and Pearson correlation coefficients

\begin{tabular}{|c|c|c|c|c|c|c|c|c|c|c|c|}
\hline & Mean & $S D$ & 1 & 2 & 3 & 4 & 5 & 6 & 7 & 8 & 9 \\
\hline $\begin{array}{l}1 \\
\text { Work-Family } \\
\text { Conflict }\end{array}$ & 0.39 & 0.15 & 1.00 & & & & & & & & \\
\hline 2 Teamwork & 0.04 & 0.16 & $-0.05^{*}$ & 1.00 & & & & & & & \\
\hline 3 Flex Time & 0.55 & 0.18 & $-0.07 * *$ & 0.01 & 1.00 & & & & & & \\
\hline $\begin{array}{l}4 \text { Leisure } \\
\text { Time }\end{array}$ & 0.02 & 0.09 & -0.01 & 0.01 & -0.01 & 1.00 & & & & & \\
\hline $\begin{array}{l}5 \\
\text { Compensation }\end{array}$ & 0.45 & 0.23 & $-0.14 * *$ & $0.15 * *$ & 0.04 & $-0.11 * *$ & 1.00 & & & & \\
\hline 6 Age & 3.49 & 1.16 & $0.06^{*}$ & 0.02 & $0.11 * *$ & $-0.12 * *$ & $0.06^{*}$ & 1.00 & & & \\
\hline 7 Work Status & 0.39 & 0.49 & $-0.05^{*}$ & $0.06^{* *}$ & $-0.08 * *$ & -0.04 & $0.13 * *$ & 0.02 & 1.00 & & \\
\hline $\begin{array}{l}8 \text { Family } \\
\text { Status }\end{array}$ & 2.40 & 0.89 & $-0.18 * *$ & 0.02 & $-0.07 * *$ & $-0.10^{* *}$ & $-0.07 * *$ & $-0.18 * *$ & $0.05^{*}$ & 1.00 & \\
\hline 9 Gender & 0.41 & 0.49 & 0.02 & 0.03 & 0.04 & 0.02 & $0.11^{* *}$ & 0.01 & $0.11 * *$ & $-0.05^{* *}$ & 1.00 \\
\hline
\end{tabular}

$* * p<0.01$ level $(2$-tailed $) * p<0.05$ level. $\quad N=1141$

\subsection{Moderation by Gender and Family Status}

Hypothesis 5 states that employees' gender will moderate the relationship between their use of flextime and perceived work-family conflict, such that the negative relationship between flextime and work-family conflict will be stronger for men compared to women. As seen in Table 2 (Model 2), gender has a significant interaction effect with flextime on work-family conflict $(\beta=-0.08, p<0.10)$, providing support to H5.

The significant, negative interaction effect of gender on work-family conflict (corresponding to H5) is presented graphically in Figure 2-a, which shows that compared to women, the work-family conflict of men reduces at a higher rate with the use of flextime. This result reveals that with increased use of flextime, the work-family conflict of men becomes significantly lower, while it stays the same for women. This supports our thesis that men perceive lower levels of work-family conflict than women in general, and the use of flextime benefits them more as compared with women.

Also, results presented in Table 2 (Model 3) show that in support of H6, marital status has a statistically significant, positive interaction effect with flextime $(\beta=0.08, p<0.05)$. This effect is presented graphically in Figure 2-b, which shows that compared to married employees (denoted as 'high family status'), the work-family conflict of single employees reduces at a higher rate with the use of flextime. This means that single employees perceive lower levels of work-family conflict and the use of flextime benefits them more as compared with married employees. 
Table 2. Direct and Moderating Effects of Human Resource Practices on Work-Family Conflict

\begin{tabular}{|c|c|c|c|c|}
\hline & Model 1 & Model 2 & Model 3 & Model 4 \\
\hline \multirow[t]{2}{*}{ Age } & 0.01 & 0.01 & 0.01 & 0.01 \\
\hline & $(0.01)$ & $(0.01)$ & $(0.01)$ & $(0.01)$ \\
\hline \multirow[t]{2}{*}{ Compensation } & $-0.08 * * *$ & $-0.08 * * *$ & $-0.08 * * *$ & $-0.08 * * *$ \\
\hline & $(0.02)$ & $(0.02)$ & $(0.02)$ & $(0.02)$ \\
\hline \multirow[t]{2}{*}{ Teamwork } & -0.03 & -0.03 & -0.03 & -0.02 \\
\hline & $(0.04)$ & $(0.04)$ & $(0.04)$ & $(0.04)$ \\
\hline \multirow[t]{2}{*}{ Leisure Time } & -0.05 & -0.06 & -0.06 & -0.06 \\
\hline & $(0.04)$ & $(0.04)$ & $(0.04)$ & $(0.04)$ \\
\hline \multirow[t]{2}{*}{ Flextime } & $-0.11 * * *$ & $-0.07 *$ & $-0.26 * * *$ & $-0.14 * * *$ \\
\hline & $(0.02)$ & $(0.03)$ & $(0.07)$ & $(0.03)$ \\
\hline \multirow[t]{2}{*}{ Gender } & $0.03 * * *$ & $0.08 * *$ & $0.03 * * *$ & $0.03 * * *$ \\
\hline & $(0.01)$ & $(0.03)$ & $(0.01)$ & $(0.01)$ \\
\hline \multirow[t]{2}{*}{ Marital Status } & $-0.03 * * *$ & $-0.03 * * *$ & $-0.07 * * *$ & $-0.03 * * *$ \\
\hline & $(0.01)$ & $(0.01)$ & $(0.02)$ & $(0.01)$ \\
\hline \multirow[t]{2}{*}{ Managerial Status } & $-0.03 * *$ & $-0.03 * *$ & $-0.03 * * *$ & $-0.08 * *$ \\
\hline & $(0.01)$ & $(0.01)$ & $(0.01)$ & $(0.03)$ \\
\hline \multirow[t]{2}{*}{ Flextime $*$ Gender } & & $-0.08 *$ & & \\
\hline & & $(0.05)$ & & \\
\hline \multirow[t]{2}{*}{ Flextime * Marital Status } & & & $0.08 * *$ & \\
\hline & & & $(0.03)$ & \\
\hline \multirow[t]{2}{*}{ Flextime $*$ Managerial Status } & & & & $0.10 * *$ \\
\hline & & & & $(0.05)$ \\
\hline \multirow[t]{2}{*}{ Constant } & $0.54 * * *$ & $0.52 * * *$ & $0.63 * * *$ & $0.56 * * *$ \\
\hline & $(0.02)$ & $(0.01)$ & $(0.04)$ & $(0.03)$ \\
\hline Adjusted R-squared & 0.07 & 0.07 & 0.08 & 0.08 \\
\hline
\end{tabular}

$* * * p<0.01 * * p<0.05 * p<0.10 . N=1141$. Dependent Variable: Work-Family Conflict. All estimates are unstandardized coefficients from weighted least squares regressions (using employee weights). 


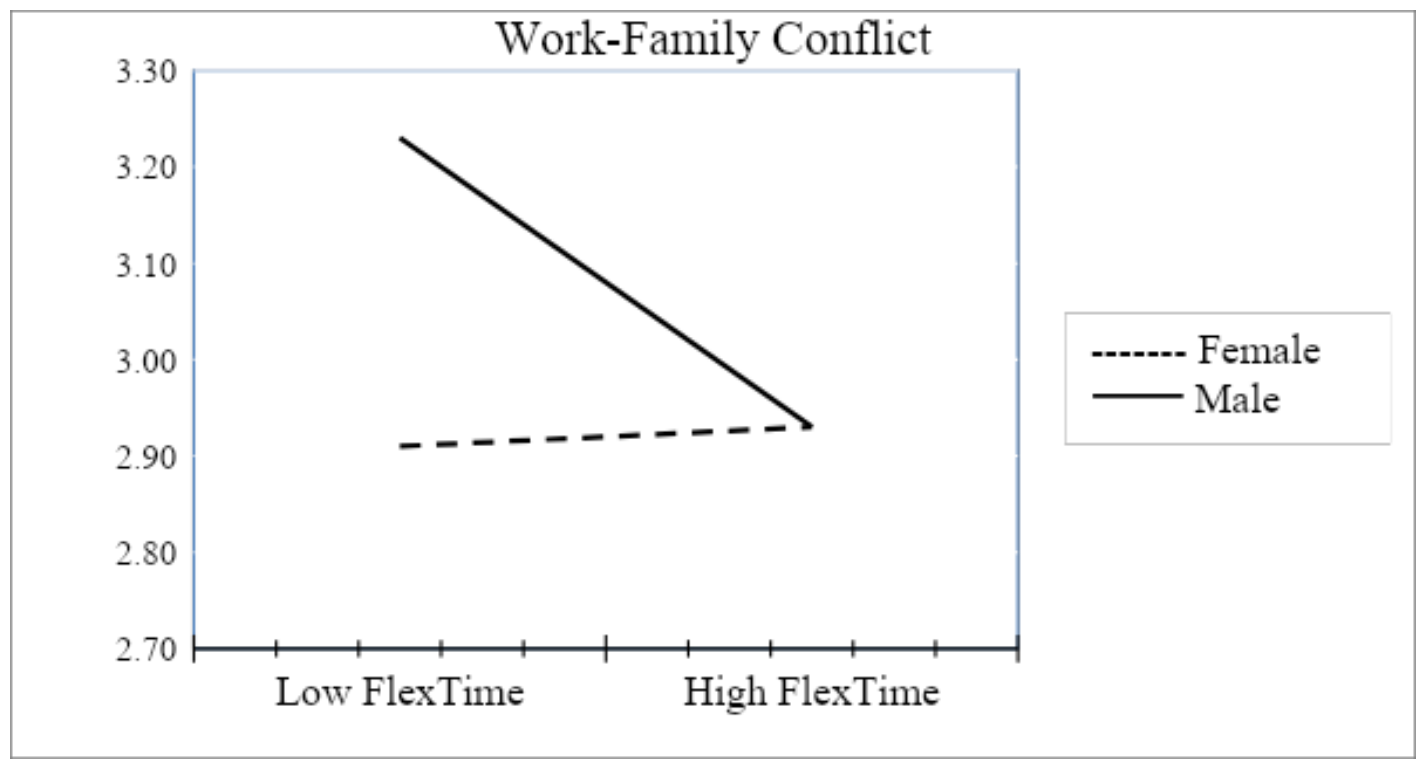

Figure 2-a. Flextime and Work-Family Conflict: Moderation by Gender

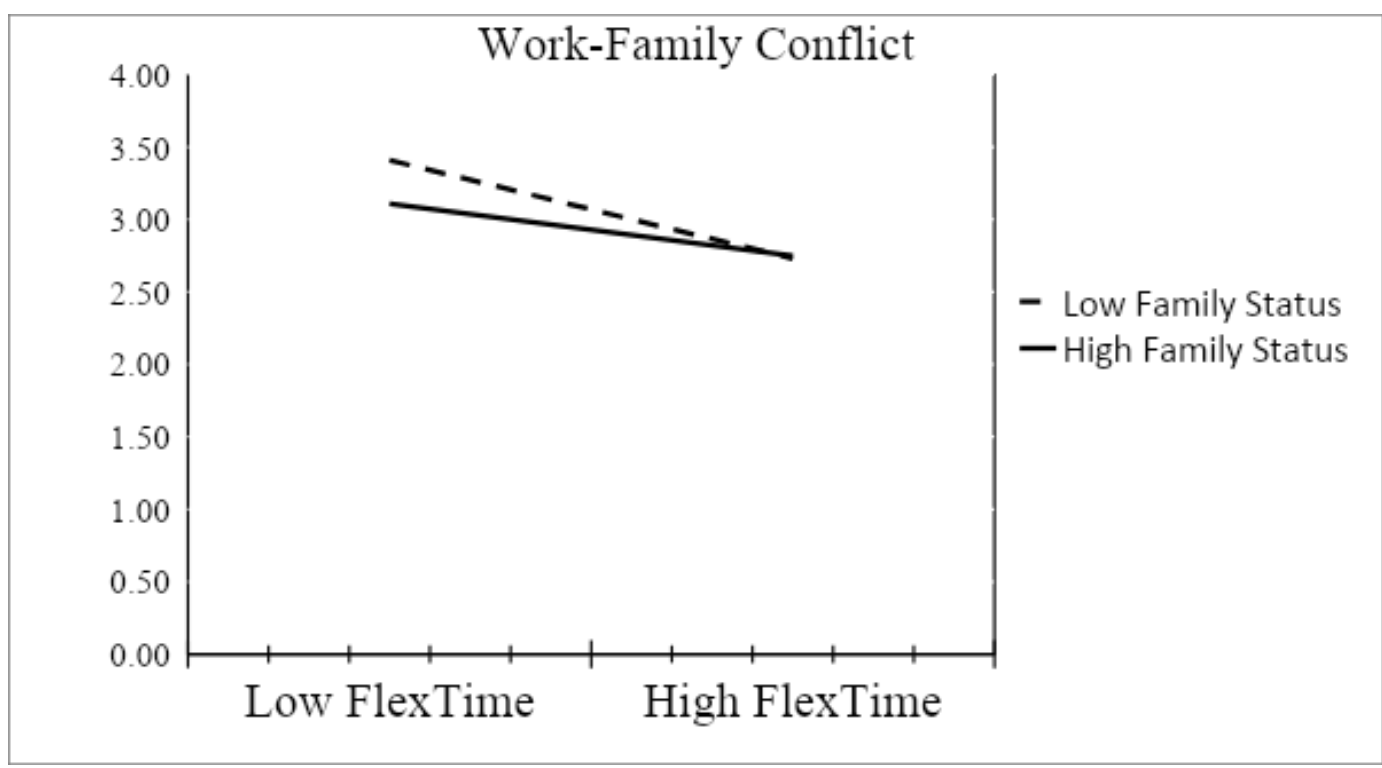

Figure 2-b. Flextime and Work-Family Conflict: Moderation by Family Status

\subsection{Moderation by Work Status}

As hypothesized in $\mathrm{H} 7$, results in Table 2 (Model 4) show that managerial status has a significant, positive interaction effect with flextime on work-family conflict $(\beta=0.10, p<0.05)$. This effect is presented graphically in Figure 2-c, which shows that compared to managers, the work-family conflict of non-managers reduces at a higher rate with the use of flextime. This means that the work status of employees does matter for their experienced work-family conflict levels and effects of flextime. Non-managerial employees perceive lower levels of work-family conflict and the use of flextime benefits them more as compared with managers. This finding is in line with the fact that managers face higher job demands and are expected to expend more resources at the workplace, thereby making their work-family conflict levels 
higher than non-managerial employees. They also may not benefit as much from the use of flexible work practices as they are expected to be available to solve workplace problems any time that they occur.

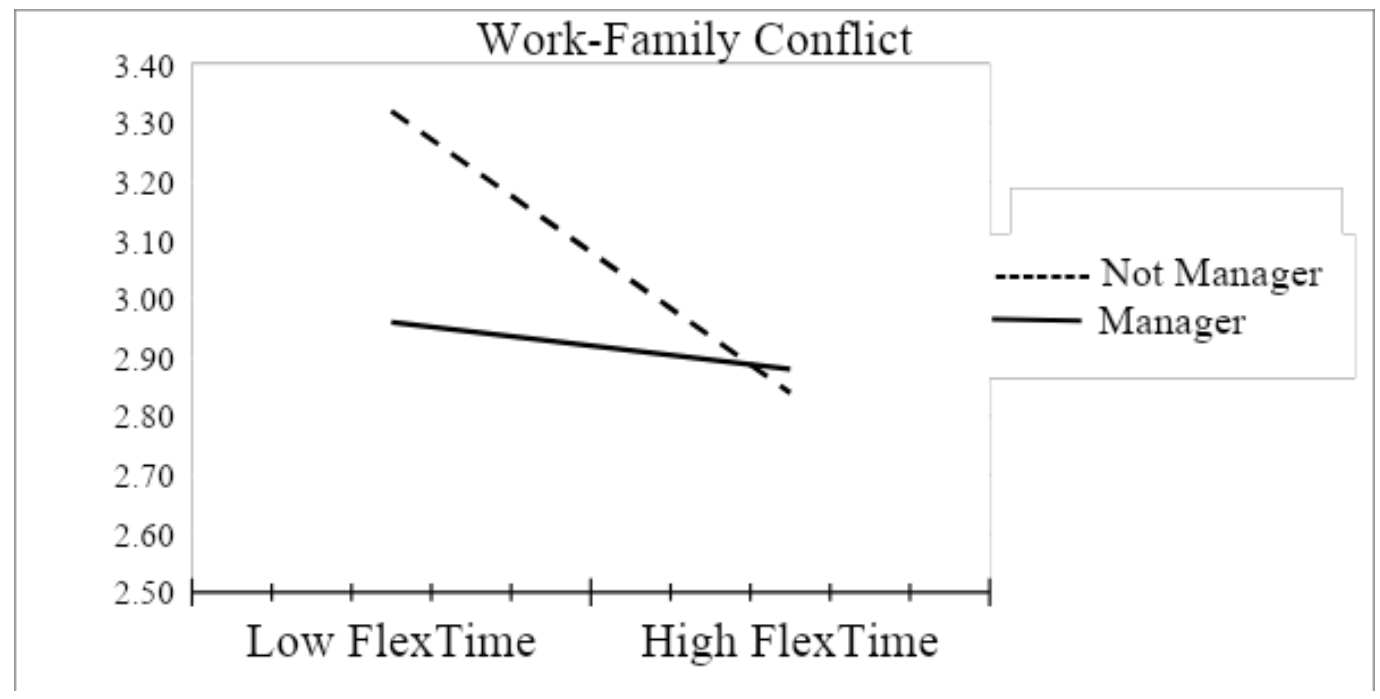

Figure 2-c. Flextime and Work-Family Conflict: Moderation by Managerial Status

\section{Discussion and Conclusion}

\subsection{Theoretical and Practical Implications}

\subsubsection{Study Contributions}

Our study makes several theoretical contributions. First, it extends the strategic human resource management literature to show that flexible work practices have a direct, positive impact on employees' work-life balance. Second, it adds to the HR literature by showing that HR practices do not work in isolation but need to be considered along with the personal situation of the employee. The implementation of HR practices such as flextime will not be effective if the same practices are available to all categories of employees. HR practice implementation needs to be flexible to accommodate employees' age, gender and marital status as important variables that determine their experienced work-family conflict. The fact that flexible work practices are gendered is highlighted in this study - men experience work-life conflict very differently than women. Also, the work status of employees determines how they experience role conflict emanating from from the work and family domains. Managers experience higher levels of work-family conflict inspite of the use of flextime. This means that other HR strategies must be made available to them to enable coping with work-family conflict. Third, our study highlights the collective impact of personal as well as organizational variables on employee work-family conflict. For example, if a manager is a married woman, that could be an extreme condition for work-family conflict experienced by the manager. While it may seem a very common scenario in reality, organizations do not necessarily provide coping mechanisms or HR strategies to help such employees. 


\subsubsection{Practical Implications}

Organizations must implement HR strategies in light of the competing roles performed by employees. Given the negative outcomes of work-family conflict for both individual as well as organizational effectiveness, implementation of HR practices must consider that different categories of employees experience them differentially, depending on their gender, marital status and managerial status. Women experience higher levels of work-family conflict inspite of using flextime. So do managerial employees as well as single employees. A one-size fits all strategy will not work for HR practice implementation. Organizational leaders must recognize the individual situations of their employees and provide flexibility in HR practices that employees may use according to their own personal situations at any given point in time. While this may seem as a demanding solution, it is not difficult to achieve practically. For example, if managers are allowed to solve workplace problems virtually, reduce facetime, as well as use flextime opportunities, it may help reduce their felt work-family conflict. Supportive HR policies for women and employees with children such as job sharing, childcare allowances will help. Incentives other than flextime may be more valuable for single employees.

\subsubsection{Limitations and Future Directions}

We recognize several limitations of our study. First, we use cross-sectional data reported by employees. However, given the detailed mode used by the UK Department of Business and Innovation to administer the Work-Life Balance Survey, we think that this is a unique data set yielding information that is not otherwise accessible. In addition, the large sample size of 1441 employees that are currently using flexible work practices gives us confidence in the power of our statistical results. Another advantage is that we include only the sample of employees that currently use flexible work practices such as flextime. By controlling for this, we limit the subjective nature of our findings and can make more objective conclusions.

While we are cautious to establish causation, our moderation results provide new insights on the personal variables that affect employee work-family conflict and we use the findings to make incremental recommendations based on what strategic HR scholars have found in the past. Future research must use longitudinal data to test whether similar effects exist over time, or do they change with the change in the personal situation of employees. Does the experienced work-family conflict alter if a managerial employee becomes a non-managerial employee for some reason? Does experienced work-family conflict depend on the team that the manager leads, or is it consistent over time? How do we provide HR practices for women employees to help them reduce their work-family conflict? An exploration of these questions will provide additional crucial insights into the management of employee work-family conflict. Given the gendered nature of work-family conflict, as well as the differential experiences of married versus single employees, research needs to highlight the business case of flexible work practice implementation, especially for women, parents and single employees.

\section{Acknowledgements}

The authors wish to thank numerous colleagues for helpful comments. We also thank the Department for Business, Innovation and Skills, Labour Market Analysis. (2012). Work-Life Balance Study, 2011: Employees' Survey. UK Data Service, for access to this data. The 
findings and views based on these data should not be attributed to the UK Data Service or its funding agency, The Economic and Social Research Council (ESRC).

\section{References}

Adams, G. A., \& Jex, S. M. (1999). Relationships between time management, control, work-family conflict, and strain. Journal of occupational health psychology, 4(1), 72. https://doi.org/10.1037/1076-8998.4.1.72

Albertsen, K., Rafnsdóttir, G. L., Grimsmo, A., Tómasson, K., \& Kauppinen, K. (2008). Workhours and worklife balance. Scandinavian Journal of Work, Environment \& Health, 34(5), 14.

Allen, T. D., Johnson, R. C., Kiburz, K. M., \& Shockley, K. M. (2013). Work-family conflict and flexible work arrangements: Deconstructing flexibility. Personnel psychology, 66(2), 345-376. https://doi.org/10.1111/peps.12012

Appelbaum, E., Bailey, T., Berg, P. B., Kalleberg, A. L., \& Bailey, T. A. (2000). Manufacturing advantage: Why high-performance work systems pay off. Cornell University Press.

Cappelli, P., Bassi, L., Katz, H., Knoke, D., Osterman, P., \& Useem, M. (1997). Change at work. Oxford University Press on Demand.

Christensen, K. E., \& Staines, G. L. (1990). Flextime: A viable solution to work/family conflict?. Journal of Family issues, 11(4), 455-476. https://doi.org/10.1177/019251390011004007

Crawford, W. S., Thompson, M. J., \& Ashforth, B. E. (2019). Work-life events theory: Making sense of shock events in dual-earner couples. Academy of Management Review, 44(1), 194-212. https://doi.org/10.5465/amr.2016.0432

Bailyn, L. (1993). Breaking the mold: Women, men, and time in the new corporate world. Simon and Schuster.

Bailyn, L., Rapoport, R., \& Fletcher, J. K. (2000). Moving corporations in the United States toward gender equity: A cautionary tale. Organizational Change \& Gender Equity, 167-179.

Baltes, B. B., Briggs, T. E., Huff, J. W., Wright, J. A., \& Neuman, G. A. (1999). Flexible and compressed workweek schedules: A meta-analysis of their effects on work-related criteria. Journal of applied psychology, 84(4), 496. https://doi.org/10.1037/0021-9010.84.4.496

Bartolome, F. Executives as human beings. Harvard Business Review, 50(6), 62-69.

Batt, R. (2002). Managing customer services: Human resource practices, quit rates, and sales growth. Academy of management Journal, 45(3), 587-597. https://doi.org/10.5465/3069383

Batt, R., \& Valcour, P. M. (2003). Human resources practices as predictors of work-family outcomes and employee turnover. Industrial Relations: A Journal of Economy and Society, 42(2), 189-220. https://doi.org/10.1111/1468-232X.00287 
Beauregard, T. A., \& Henry, L. C. (2009). Making the link between work-life balance practices and organizational performance. Human resource management review, 19(1), 9-22. https://doi.org/10.1016/j.hrmr.2008.09.001

Becker, B. E., \& Huselid, M. A. (2006). Strategic human resources management: where do we go from here? Journal of Management, 32(6), 898-925. https://doi.org/10.1177/0149206306293668

Berg, P., Kalleberg, A. L., \& Appelbaum, E. (2003). Balancing work and family: The role of high-commitment environments. Industrial Relations: A Journal of Economy and Society, 42(2), 168-188. https://doi.org/10.1111/1468-232X.00286

Bernardo, C., Paleti, R., Hoklas, M., \& Bhat, C. (2015). An empirical investigation into the time-use and activity patterns of dual-earner couples with and without young children. Transportation Research Part A: Policy and Practice, 76, 71-91. https://doi.org/10.1016/j.tra.2014.12.006

Beutell, N. J., \& Greenhaus, J. H. (1982). Interrole conflict among married women: The influence of husband and wife characteristics on conflict and coping behavior. Journal of Vocational Behavior, 21(1), 99-110. https://doi.org/10.1016/0001-8791(82)90055-0

Burke, R. J., Weir, T., \& DuWors Jr, R. E. (1979). Type A behavior of administrators and wives' reports of marital satisfaction and well-being. Journal of Applied Psychology, 64(1), 57. https://doi.org/10.1037/0021-9010.64.1.57

Byron, K. (2005). A meta-analytic review of work-family conflict and its antecedents, Journal of Vocational Behavior, 67(2), 169-198. https://doi.org/10.1016/j.jvb.2004.08.009

De Menezes, L. M., \& Kelliher, C. (2017). Flexible working, individual performance, and employee attitudes: Comparing formal and informal arrangements. Human Resource Management, 56(6), 1051-1070. https://doi.org/10.1002/hrm.21822

Duxbury, L., \& Dole, G. (2015). Squeezed in the middle: Balancing paid employment, childcare and eldercare. Flourishing in life, work and careers: Individual wellbeing and career experiences, 141-166.

Duxbury, L., Higgins, C., \& Lee, C. (1994). Work-family conflict: A comparison by gender, family type, and perceived control. Journal of family Issues, 15(3), 449-466. https://doi.org/10.1177/019251394015003006

Duxbury, L. E., \& Higgins, C. A. (1991). Gender differences in work-family conflict. Journal of applied psychology, 76(1), 60. https://doi.org/10.1037/0021-9010.76.1.60

Eaton, S. C. (2003). If you can use them: Flexibility policies, organizational commitment, and perceived performance. Industrial Relations: A Journal of Economy and Society, 42(2), 145-167. https://doi.org/10.1111/1468-232X.00285

Ernst Kossek, E., \& Ozeki, C. (1998). Work-family conflict, policies, and the job-life satisfaction relationship: A review and directions for organizational behavior-human resources 
$\begin{array}{llllll}\text { research. Journal of } & \text { applied }\end{array}$ https://doi.org/10.1037/0021-9010.83.2.139

Fagan, C., \& Burchell, B. (2002). Gender, Jobs and Working Conditions in the European Union.

Frone, M. R., Russell, M., \& Cooper, M. L. (1992). Antecedents and outcomes of work-family conflict: testing a model of the work-family interface. Journal of applied psychology, 77(1), 65. https://doi.org/10.1037/0021-9010.77.1.65

Fu, C. K., \& Shaffer, M. A. (2001). The tug of work and family: Direct and indirect domain-specific determinants of work-family conflict. Personnel review, 30(5), 502-522. https://doi.org/10.1108/EUM0000000005936

Gallie, D. (2002). Work Intensification in Europe 1996-2001. Paper presented at Colloque “Organization, Intensity of Work, Quality of Work', Paris, 21/22 November 2002.

Goff, S. J., Mount, M. K., \& Jamison, R. L. (1990). Employer supported child care, work/family conflict, and absenteeism: A field study. Personnel psychology, 43(4), 793-809. https://doi.org/10.1111/j.1744-6570.1990.tb00683.x

Golden, L. (2001). Flexible work schedules: Which workers get them? American Behavioral Scientist, 44(2001), 1157-1178. https://doi.org/10.1177/00027640121956700

Goldenhar, D. (2003). The benefits of flexible work arrangements, Advancing Women Professional and The Jewish Community, New York (2003).

Green, F. (2001). It's been a hard Day's Night: The Concentration and Intensification of Work in late $20^{\text {th }}$ Century Britain. British Journal of Industrial Relations, 39(1), 53-80. https://doi.org/10.1111/1467-8543.00189

Green, F. (2002). Work Intensification, Discretion and the Decline in Well-Being at Work. Paper presented for the Conference on Work Intensification, Paris, 20-21 November, 2002.

Green, F., \& McIntosh, S. (2001). The intensification of work in Europe. Labour Economics, 8(2), 291-308. https://doi.org/10.1016/S0927-5371(01)00027-6

Greenhaus, J. H., \& Beutell, N. J. (1985). Sources of conflict between work and family roles. Academy of management review, 10(1), 76-88. https://doi.org/10.5465/amr.1985.4277352

Greenhaus, J. H., \& Kopelman, R. E. (1981). Conflict between work and nonwork roles: Implications for the career planning process. Human Resource Planning, 4(1), 1-10.

Greiff, B. S., \& Munter, T. P. K. (New York: New American Library, 1980).

Grönlund, A., \& Öun, I. (2018). In search of family-friendly careers? Professional strategies, work conditions and gender differences in work-family conflict. Community, work \& family, 21(1), 87-105. https://doi.org/10.1080/13668803.2017.1375460 
Haar, J. M. (2013). Testing a new measure of WLB: A study of parent and non-parent employees from New Zealand. The International Journal of Human Resource Management, 24(17/18), 3305-3324. https://doi.org/10.1080/09585192.2013.775175

Hammer, L. B., Neal, M. B., Newsom, J. T., Brockwood, K. J., \& Colton, C. L. (2005). A longitudinal study of the effects of dual-earner couples' utilization of family-friendly workplace supports on work and family outcomes. Journal of Applied Psychology, 90(4), 799. https://doi.org/10.1037/0021-9010.90.4.799

Herman, J. B., \& Gyllstrom, K. K. (1977). Working Men and Women: Inter-and Intra-Role Conflict*. Psychology of Women Quarterly, 1(4), 319-333. https://doi.org/10.1111/j.1471-6402.1977.tb00558.x

Hochschild, A. (1997). The time bind. WorkingUSA, 1(2), 21-29. https://doi.org/10.1111/j.1743-4580.1997.tb00019.x

Hoobler, J. M., Wayne, S. J., \& Lemmon, G. (2009). Bosses' perceptions of family-work conflict and women's promotability: Glass ceiling effects. Academy of management journal, 52(5), 939-957. https://doi.org/10.5465/amj.2009.44633700

Jiang, K., Lepak, D. P., Hu, J., \& Baer, J. C. (2012). How does human resource management influence organizational outcomes? A meta-analytic investigation of mediating mechanisms. Academy of management Journal, 55(6), 1264-1294. https://doi.org/10.5465/amj.2011.0088

Kahn, R. L., Wolfe, D. M., Quinn, R. P., Snoek, J. D., \& Rosenthal, R. A. (1964). Organizational stress: Studies in role conflict and ambiguity.

Kalliath, T., \& Brough, P. (2008). Work-life balance: A review of the meaning of the balance construct. Journal of management \& organization, 14(3), 323-327. https://doi.org/10.1017/S1833367200003308

Kasper, H., Meyer, M., \& Schmidt, A. (2005). Managers dealing with work-family-conflict: an explorative analysis. Journal of Managerial Psychology, 20(5), 440-461. https://doi.org/10.1108/02683940510602978

Katz, D., \& Kahn, R. L. (1978). The social psychology of organizations (Vol. 2, p. 528). New York: Wiley.

Keith, P. M., \& Schafer, R. B. (1980). Role strain and depression in two-job families. Family Relations, 483-488. https://doi.org/10.2307/584462

Kelloway, E. K., Gottlieb, B. H., \& Barham, L. (1999). The source, nature, and direction of work and family conflict: A longitudinal investigation. Journal of occupational health psychology, 4(4), 337. https://doi.org/10.1037/1076-8998.4.4.337

Kossek, E. E., Baltes, B. B., \& Matthews, R. A. (2011a). How work-family research can finally have an impact in organizations. Industrial and organizational psychology, 4(3), 352-369. https://doi.org/10.1111/j.1754-9434.2011.01353.x 
Kossek, E. E., Baltes, B. B., \& Matthews, R. A. (2011b). Innovative ideas on how work-family research can have more impact. Industrial and organizational psychology, 4(3), 426-432. https://doi.org/10.1111/j.1754-9434.2011.01367.x

Kossek, E. E., Colquitt, J. A., \& Noe, R. A. (2001). Caregiving decisions, well-being, and performance: The effects of place and provider as a function of dependent type and work-family climates. Academy of management Journal, 44(1), 29-44. https://doi.org/10.2307/3069335

Kossek, E. E., \& Nichol, V. (1992). The effects of on-site child care on employee attitudes and $\begin{array}{llll}\text { performance. } & \text { Personnel 485-509. }\end{array}$ https://doi.org/10.1111/j.1744-6570.1992.tb00857.x

Kossek, E. E., \& Ozeki, C. (1999). Bridging the work-family policy and productivity gap: A literature review. Community, Work \& Family, 2(1), 7-32. https://doi.org/10.1080/13668809908414247

Kossek, E. E., \& Van Dyne, L. (2008). Face-time matters: A cross-level model of how work-life flexibility influences work performance of individuals and groups. In Handbook of work-family integration (pp. 305-330). Academic Press. https://doi.org/10.1016/B978-012372574-5.50020-X

Lepak, D. P., Liao, H., Chung, Y., \& Harden, E. E. (2006). A conceptual review of human resource management systems in strategic human resource management research. In Research in personnel and human resources management (pp. 217-271). Emerald Group Publishing Limited.

Linehan, M., \& Walsh, J. S. (2000). Work-family conflict and the senior female international manager. British Journal of Management, $11, \quad$ S49-S58. https://doi.org/10.1111/1467-8551.11.s1.5

Lingard, H., \& Francis, V. (2005). Does work-family conflict mediate the relationship between job schedule demands and burnout in male construction professionals and managers?. $\begin{array}{llll}\text { Construction Management and } & \text { 23(7), }\end{array}$ https://doi.org/10.1080/01446190500040836

Loerch, K. J., Russell, J. E., \& Rush, M. C. (1989). The relationships among family domain variables and work-family conflict for men and women. Journal of Vocational Behavior, 35(3), 288-308. https://doi.org/10.1016/0001-8791(89)90031-6

Matias, M., Ferreira, T., Vieira, J., Cadima, J., Leal, T., \& Mena Matos, P. (2017). Workplace family support, parental satisfaction, and work-family conflict: Individual and crossover effects among dual-earner couples. Applied Psychology, 66(4), 628-652. https://doi.org/10.1111/apps.12103

Neal, M. B., \& Hammer, L. B. (2017). Working couples caring for children and aging parents: Effects on work and well-being. Psychology Press. https://doi.org/10.4324/9781315083865 


\section{Mll Macrothink}

International Journal of Human Resource Studies

ISSN 2162-3058

2019, Vol. 9, No. 4

Nomaguchi, K. M., \& Fettro, M. N. (2017). Why do mothers experience more work-family conflict when their children are younger. Working paper presented at the Population Association of America Annual Meeting.

Park, Y., \& Fritz, C. (2015). Spousal recovery support, recovery experiences, and life satisfaction crossover among dual-earner couples. Journal of Applied Psychology, 100(2), 557. https://doi.org/10.1037/a0037894

Perlow, L. A. (1997). Finding time: How corporations, individuals, and families can benefit from new work practices. Cornell University Press.

Perry-Smith, J. E., \& Blum, T. C. (2000). Work-family human resource bundles and perceived organizational performance. Academy of Management Journal, 43(6), 1107-1117. https://doi.org/10.2307/1556339

Pleck, J. H., Staines, G. L., \& Lang, L. (1980). Conflicts between work and family life. Monthly Lab. Rev., 103, 29.

Ratten, V., Ryan, T. D., \& Sagas, M. (2009). Relationships between pay satisfaction, work-family conflict, and coaching turnover intentions. Team Performance Management: An International Journal.

Ramsay, H., Scholarios, D., \& Harley, B. (2000). Employees and high-performance work systems: testing inside the black box. British Journal of industrial relations, 38(4), 501-531. https://doi.org/10.1111/1467-8543.00178

Reilly, P. (2001). Flexibility at Work: Balancing the interests of employers and employee. Gower Publishing Limited, Hampshire.

Russell, H., O'Connell, P. J., \& McGinnity, F. (2009). The impact of flexible working arrangements on work-life conflict and work pressure in Ireland. Gender, Work \& Organization, 16(1), 73-97.

Scandura, T. A., \& Lankau, M. J. (1997). Relationships of gender, family responsibility and flexible work hours to organizational commitment and job satisfaction. Journal of Organizational Behavior: The International Journal of Industrial, Occupational and Organizational Psychology and Behavior, 18(4), 377-391.

Schein, V. E. (1973). The relationship between sex role stereotypes and requisite management characteristics. Journal of applied psychology, 57(2), 95.

Shih, H. A., Chiang, Y. H., \& Hsu, C. C. (2010). High involvement work system, work-family conflict, and expatriate performance-examining Taiwanese expatriates in China. The International Journal of Human Resource Management, 21(11), 2013-2030.

Shockley, K. M., \& Allen, T. D. (2007). When flexibility helps: Another look at the availability of flexible work arrangements and work-family conflict. Journal of Vocational Behavior, 71(3), 479-493. 


\section{Macrothink}

International Journal of Human Resource Studies

ISSN 2162-3058 2019, Vol. 9, No. 4

Stock, R. M., Bauer, E. M., \& Bieling, G. I. (2014). How do top executives handle their work and family life? A taxonomy of top executives' work-family balance. The International Journal of Human Resource Management, 25(13), 1815-1840.

Sturges, J., \& Guest, D. (2004). Working to live or living to work? Work/life balance early in the career. Human Resource Management Journal, 14(4), 5-20.

Tausig, M., \& Fenwick, R. (2001). Unbinding time: Alternate work schedules and work-life balance. Journal of family and economic issues, 22(2), 101-119.

Thomas, L. T., \& Ganster, D. C. (1995). Impact of family-supportive work variables on work-family conflict and strain: A control perspective. Journal of applied psychology, 80(1), 6.

Tipping, S., Chanfreau, J. P., \& Tait, C. (2012). The Fourth Work-Life Balance Employee Survey, Department for Business, Innovation and Skills (BIS), London, 2012.

Vieira, J. M., Matias, M., Lopez, F. G., \& Matos, P. M. (2016). Relationships between work-family dynamics and parenting experiences: A dyadic analysis of dual-earner couples. Work \& Stress, 30(3), 243-261.

Voydanoff, P. (1988). Work role characteristics, family structure demands, and work/family conflict. Journal of Marriage and the Family, 749-761.

White, M., Hill, S., McGovern, P., Mills, C., \& Smeaton, D. (2003). 'High-performance' management practices, working hours and work-life balance. British journal of industrial Relations, 41(2), 175-195.

Zhang, J., \& Liu, Y. (2011). Antecedents of work-family conflict: Review and prospect. International journal of business and management, 6(1), 89 .

\section{Copyright Disclaimer}

Copyright for this article is retained by the author(s), with first publication rights granted to the journal.

This is an open-access article distributed under the terms and conditions of the Creative Commons Attribution license (http://creativecommons.org/licenses/by/4.0/). 